\title{
169. 非相称虑材システムの特性の検討（第三報)
}

Examination of property of asymmetric system (3rd report)

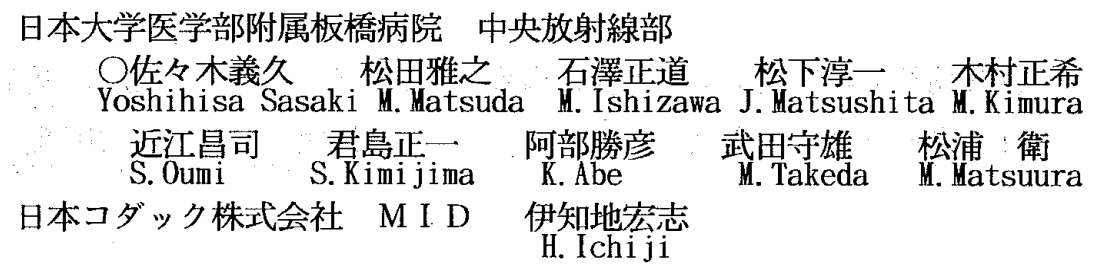

【目的】現在発売されている非相称感材インサイトシステムは、高濃度領域のコントラストを得るために、 スクリーンの感度をフロント、バック近づけて使用するケースが多い。しかし、粒状の劣化などマイナス因 子もあり、そのバランスが重要である。今回メーカーにより特に高濃度領域の画質向上のためにフロント乳 剤特性を改良したフィルムが試作された。我々はそれを入手し評価する機会を得たので、従来のインサイト フィルムと併せて評価し、最適システムの検討を行ったので報告する。

【方法、結果】フィルムは、試作品[E 2]、インサイト[ I T ]、及びT.MC / R A [ T M C ]を用い、組み合 わせたスクリーンはフロント側をH Cフロント[H C f ]一定とし、バック側をH Cバック〔HC b]、LANEX REGULER[R E G]、LANEX MEDIUM[ME D ]、H Cフロント[HC f ]とした。( T M C / R A はフロントLANEX FINE、バックMEDIUM）以下〔]のとおり略称する。

最初に組み合わせたシステムの適した管電圧を求めるために アクリルステップを各電圧ごとに撮影しコントラスト変化を調 ベた。肺野想定をアクリル $6 \mathrm{~cm}$ として濃度 $1,78 \pm 0,02$ で撮影し、同条件にて縦隔想定の $16 \mathrm{~cm}$ 落クリルを撮影した。 F i g. 1 は上段に肺野想定部（アクリル厚 1 c m の濃度差） を、下段に縦隔想定部 (アクリル厚 2 c mの濃度差) を示した。 肺野想定部では当然管電圧を上げれば各システムともコントラ ストは低下する傾向にあるが、フィルム間で比較すると、H C b の場合 I Tの方がコントラストは高いが、ME DやHC f の ようにバックの感度を下げることで、逆に E 2 が高コントラス トとなる。また、䋡隔想定部では、管電在を上げることで、線 コントラストの低下と濃度上昇に伴うフィルムガンマ変化との バランスによりシステム間に差がある。 R E G，MEDでは 1 $00 \mathrm{kV} \sim 11.0 \mathrm{kV}$ が高い値を示した。また、縦隔想定部に ついては濃度が異なるため視覚的因子が重要となると考え、同 様にバーガーファントムによる視覚評洒を行った。各管電压毎 の信号検出率を F i g.2に示す。REGは $100 \mathrm{kV} \sim 11$ $0 \mathrm{kV} 、 \mathrm{MED} 110 \mathrm{kV} \sim 120 \mathrm{kVが}$ 高い值を示した。 H C f . は䋡隔想定濃度が低いせいか高い管電厓設定ほどよい傾 向がみられた。以上の結果より判断しシステムによる適した管 電圧を、HC f $130 \mathrm{kV} 、 M E D 110 \mathrm{kV} 、 \mathrm{REG} 100$ $\mathrm{kV} 、 \mathrm{HCb} 80 \mathrm{kV} 、 T M C 100 \mathrm{kV}$ とした。

次に決定した撮影電压で胸部ファントムを撮影し視覚評価を 行った。観察者は技師 10 名で、肺野部之縦隔部についてをサ ーストンの一対此較法にて尺度化し評価した。F i g : 3 は横 軸に肺野部、縦軸に䋡隔部として尺度值をとり、その交点に各 システムをプロットした。肺野部、䋡隔部の評価結果は相反守 るが、MEDのE 2 は両方でよい傾向にある。次にボランティ アにより胸部撮影を行い評価した。T a b. 1 に評価した被写 体 A、B、Cの強度分布、評価したシステム、評価部位 6 項目 を示す。評価方法は、サーストンの一対比較法で、観察者は技 師 10 名に加え放射線科医 5名、計 15 名で行った。F i g. 4 は評価した 6 項目の尺度值をレーダーチャートで表した。胸 憬が薄く肺野と縱隔の濃度差が少ない被写体Aではほとんどの 項目でMEDのE 2がよくなり、被写体 B や Cでは心胹や横隔 膜に重なる部位でREGのE 2 がよく、続いてMEDのE 2 が 高い值を示した。

【まとめ】試作フィルム $\mathrm{E} 2$ は、組み合わせるスクリーンの感 度比 (フロント/バック) が小さい程、高濃度部のコントラス トが効果的に向上する。胸部撮影システムには、管電在 110 k Vでスクリーン HCf $/$ ME Dの組み合わせが適していた。 また、視覚評価において試作フィルム $\mathrm{E} 2$ は従来のインサイト フィルムに対し画質の向上が認められた。

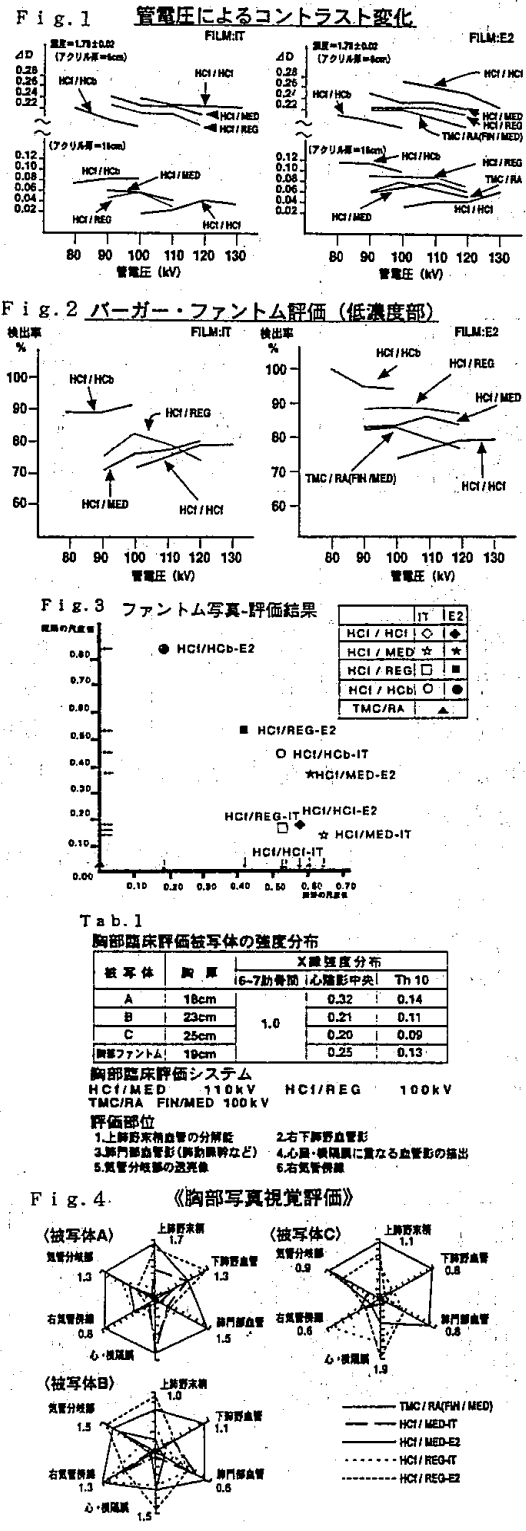

